\title{
THE NURSES AS HEALTHCARE WARRIORS IN COVID-19: PUBLIC HEALTH PERSPECTIVE
}

\author{
Prof. Dr. Gitumoni Konwar \\ Dean cum Principal Royal School of Nursing, \\ The Assam Royal Global University
}

\author{
Ms. Urmijyoti Deori \\ Assistant Professor, Royal School of Nursing, \\ The Assam Royal Global University
}

Article DOI: https://doi.org/10.36713/epra5406

\begin{abstract}
The year 2020 is announced as "the year of the Nurses and midwives" by the World Health Organization to commemorate 200-year birth anniversary of Florence Nightingale. The declaration has given true sense by the outbreak of novel CORONA virus since the beginning of the year. The nurses are the frontline fighters against COVID-19 to save the humankind. They put their lives at risk and perform their duties and responsibilities round the clock towards the community, public health and hygiene. Nurses have been showing the act of heroism, be it during the wars, epidemics and at times of disasters such as Covid-19. Nurses are facing many challenges in carrying out their duties and one of the biggest challenges is shortage of nurses, due to which they are overloaded with work. Nurses play a crucial role in the healthcare delivery system and nursing services has a great impact on health outcome of patients and public. The nurses are the backbone of the healthcare services. The nurses play a vital role towards the improvement of public health and hygiene with their independent practice. There is incredible scope to utilize the qualified nurses in public health and hygiene in developing countries like India to improve the wellbeing and quality of life of community dwellers. The emphasis must be given in utilization of the professional nurses in the public health sector.
\end{abstract}

KEY WORDS: Nurses, COVID-19, challenges, Independent role and public health perspective.

\section{COVID-19 AS A GLOBAL CRISIS}

The outbreak of Corona virus was first reported in Wuhan City of China in the month of December 2019. It has soon spread rapidly to all over the world making it globally pandemic. The WHO has declared COVID-19 as a public health emergency of international concern on January 30, 2020. As on October 05, 2020, there are 35,387,775 confirmed cases, 1,041,537 deaths, and 26,609,676 recovered globally. The most common sign and symptoms of COVID-19 are fever, cough followed by shortness of breath, fatigue, muscle pain, headache, diarrhea, difficulty in breathing. Some patients may develop life threatening complications like septic shock, pulmonary edema, severe pneumonia and respiratory distress syndrome. ${ }^{1}$

\section{NURSES IN COVID-19 PANDEMIC}

The world health organization has declared in 2019 that the year 2020 will be the year of Nurses and midwives. As the year 2020 arrives, the entire world gets engulfed by a new disease namely, COVID-19. The year 2020 indeed proven to be the year of the nurses as the whole nursing community came in the forefront as the warriors to fight the disease. Nurses are working round the clock with limited resources quite often and putting their own lives at risk for the sake of saving humankind. Nurses are managing the crisis with full responsibilities by screening the patients, placing and giving care to the patients in COVID-19 Zone. Nurses especially who are working in the ICUs are facing the unprecedented level of overwork and often continue working without adequate rest and recuperation. In many instances the nurses' own mental and physical wellbeing are not taken care of properly 
but still they happily accept their responsibilities towards their duty in the pandemic crisis. ${ }^{2}$

The COVID-19 care area is a restricted zone where only healthcare workers with full PPE can enter. At this crucial time the patients get mentally distressed for being away from their family. The nurses play a pivotal role in reassuring the patients while taking care of their physical as well as mental health needs. It's not easy for the nurses to follow their call of duty with the PPE wearing for 6 hours a day which sometimes become 12 hours. While on PPE they cannot drink water, cannot go to washroom or cannot leave the ward no matter what. Wearing the PPE itself takes about 20 minutes of time. They get scar marks below their eyes due to prolong wearing of the goggles and their uniform gets filled with sweat. ${ }^{3}$

\section{NURSES ROLE IN BREAKING THE CHAIN OF TRANSMISSION: COVID-19}

According to CDC COVID-19 response team, multiple roles are played by the nurses to fight the pandemic crisis. They cover mainly the five domains; the first domain is providing health awareness like performing hand hygiene, avoid touching the eyes, nose and mouth, wearing a mask, maintaining distance etc to reduce the rate of transmission and improve the status of public health and hygiene. They also take part in the screening services and support the public health system of the community. The second domain is preventing the nosocomial infection by implementing standard precautions and educating the patients, families and healthcare staffs. The third domain is taking special considerations and preparations for patients in long term facilities and nursing homes as they are more vulnerable to COVID-19 infection. The fourth domain is to protect the patients with immune compromised and chronic diseases like diabetes mellitus, chronic obstructive pulmonary disease etc. The fifth domain is taking care of the patients with COVID-19 both in the acute and critical conditions. ${ }^{4}$

The nurses' knowledge and skills in handling the people to improve the quality of life by improving the well-being of the public health is crucial. Hence, for the Health Services planning and implementations, it is very essential to integrate the nursing professionals.

\section{SOCIETY IMAGE OF NURSES AS HEALTH WARRIORS}

The COVID- 19 outbreak has led the media to focus on the nurses and present the image of nurses as frontline warriors to the public. People often imagine heroes with uniforms. This global pandemic has given a new image to the nurses as heroes wearing N-95 mask and other Personal Protective Equipment (PPE).
People have recognized the nurses for their act of bravery, commitments, advocacy, educating people, taking responsibilities etc while fighting against COVID-19. Nurses not only served the people in this global crisis with sheer dedication and compassion, they have also fought for their own safety as many nurses have been infected and died of the COVID-19 while taking care of the patients. ${ }^{5}$

Nurses are viewed today as the heroes of COVID-19 crisis but they have always been playing the role of Healthcare warriors, be it during the wars, epidemics or any disasters. Nurses are directly facing the threat of the COVID-19 while taking care of the patients. Being at the frontline, nurses are not only helping the COVID-19 patients to get recovered but also educating the public how to stay safe and healthy. ${ }^{6}$

\section{CHALLENGES FOR THE NURSES}

The number of registered nurses in India who actively work in health sector is mere 3.07 million. This number is not adequate enough to balance the nurse-patient ratio as per the WHO recommendations. As on May 2020 more than 260 nurses in India have lost their lives while performing their duties in this COVID-19 pandemic. About 156 nurses tested positive and a huge number of nurses had to be quarantined due to getting close contact with the infected patients. ${ }^{7}$

About $88 \%$ of the nurses work for $8-10$ hours a day along with over time work twice or thrice a month. About $74 \%$ of nurses have to stand for 4-6 hours at one stretch. About $20 \%$ of nurses perform double duty shift twice a month, $26 \%$ were asked to work on their off days twice a month. India was already facing the shortage of 2 million nurses before this Corona virus outbreak strike. The nurse patient ratio is just 2.1 nurses per 1,000 populations. This shortage has put much strain to the nurse workforce across the country. ${ }^{8}$

\section{HEALTH OF THE HEALTHCARE WARRIORS}

The nurses and other healthcare workers are constantly exposed to hazardous environment. There are various hazards in the health care Industry ranging from exposure to biological hazards like disease causing microorganisms to exposure to chemicals such as glutaraldehyde and ethylene dioxide. They are also subjected to physical hazards like radiation exposure and noise. Apart from these, their job demands heavy lifting and prolong standing. According to a report by WHO, the percutaneous sharp injuries among healthcare workers were found to be 3 million per year. It was also reported that $40 \%$ of Hepatitis B, $40 \%$ of Hepatitis C and $4.4 \%$ of HIV infections among healthcare workers are due to needle stick injuries. 
About 1000 healthcare workers die each year due to occupational HIV, which could be prevented. Despite this, about $80 \%$ of healthcare workers are not immunized against Hepatitis B. It is very important to give priority to the occupational health of the healthcare workers because if they stay healthy then only a healthy society can be built. ${ }^{9}$

A study done by Godrej Interio to understand the work environment for nurses in India revealed that the nurses are affected with long duration of work and over workload. About $90 \%$ of nurses suffer from musculoskeletal disorder, $61 \%$ suffers from neck pain, and $51 \%$ suffer from recurrent leg pain and knee pain. Again about $51 \%$ of nurses suffer from lower back pain. ${ }^{10}$

\section{HELPLINE SET UP FOR HEALTHCARE WORKERS}

On $15^{\text {th }}$ April 2020, the supreme court of India decided to set up helpline for the healthcare warriors. The helpline will be redressing their grievances such as deduction in the salary, delayed payment of salary, non-availability of Personal Protective Equipment (PPE), getting evicted from their rented accommodations etc.

A bench of Justices comprising NV Ramana, SK Kaul and BR Gavai has included the petition filed by the United Nurses association (UNA) to formulate a National COVID-19 Management protocol for addressing any serious issues and safety concerns of the healthcare workers who are taking care of the COVID19 patients. Advocate Subhash Chandran KR said that around 150-200 nurses got infected with the corona virus and about 600-700 healthcare workers are in quarantine. They are asked to vacate their accommodations from their landlords due to their close contact with the patients. Solicitor general Tushar Mehta said that the Ministry of Home Affairs will set up helpline number for the healthcare warriors to redress their complaints and grievances and it will be addressed within 2 hours. ${ }^{11}$

\section{EXPERIENCES SHARED BY NURSES IN THEIR COVID-19 JOURNEY}

Many nurses across the Country shared their experiences in their COVID-19 journey while managing the COVID-19 patients. Some of their experiences are cited below. ${ }^{12}$

Mr. Ajo Jose, nursing officer at emergency department of Dr. RML Hospital, Delhi was chosen by the Health Ministry as one of the team members to be sent to Coronavirus- hit city of Wuhan, China to evacuate Indian nationals. There was an option for denying but Mr. Jose happily accepted and been part of the team. They have evacuated about 370 Indians. They had to change their PPE every time they went out of the aircraft and had to safely dispose off. There was a high chance of getting infected but when he has seen a deep sense of gratitude in the eyes of the passengers. It made him feel his every hardship worthwhile.

Mr. Manu Joseph, working as nursing officer in Safdarjung hospital, Delhi, was also chosen to be the part of the team member to evacuate Indians from Wuhan City, China. His family feared to let him go but he chose to go. He said the most difficult task was to be in PPE kit for several hours as it feels suffocating. They successfully carried out the mission and the entire team was felicitated by the Health Minister for their bravery act.

Ms. Asmol Chacko, staff nurse at Kottayam Medical College said that it is very difficult to be in the PPE kit for long duration of time. They cannot communicate properly with the other healthcare team which is quite frustrating. Ms. Asmol took it as a challenge and did not let it make her feel weak. She was in quarantine for two weeks after taking care of elderly couple with COVID-19 aged 88 and 90. While in quarantine, she followed a daily self care routine, read books and exercised. She is tested negative and back to work again with same positivity.

Mrs. Pratima Nair works as a Matron at King Edward VII memorial Hospital in Mumbai which is the most affected city in India. She said they got the order for converting all the wards into COVID-19 care center overnight. It was very difficult because they had to do structural changes of the wards, remove equipments and arrange PPEs drugs etc in just one day. Finally they managed to do everything on time with the help of hospital administration team. She also said that there were fear and anxiety among the nurses to take care of COVID-19 patients. She arranged many training programs for the nurses regarding taking care of COVID-19 patients. She also arranged counseling sessions for the nurses to manage their stress and fear.

Archana Rana, working as senior nursing officer at AIIMS, Delhi volunteered to work in COVID-19 designated Center. Initially her family was not happy for her this decision but finally understood her invincible spirit. She said she is away from her family and cannot take care of her kids but she has to serve the people first in this crisis situation.

\section{IMPACT OF NURSING SERVICES ON HEALTH OUTCOMES}

A study done in 2014 revealed that the mortality rate of patients decreased by $10.9 \%$ after the hospitals increase their recruitment of nursing staffs by $10 \%$. It was also found that the patients who had post-operative 
complications experienced speedy recovery in the hospitals with strong nurse workforce. ${ }^{13}$

A review analysis of 61 reviews was done on impact of professional nursing services on patients' health globally. It revealed that the risk of mortality among patients is decreased, if well-educated nursing workforce is available at the acute care areas. Moderate evidence was also found that well qualified nurses can produce good health outcomes among the patients which is equivalent to the doctors who treat the patients with some chronic health problems. This outcome is particularly in the primary care centers and the Nurseled clinics.

Therefore, the highly qualified nurses like graduate, postgraduate and doctorate nurses need to be allowed for independent practice in India, which is yet to come. ${ }^{14}$

\section{PROFESSIONAL INPUTS OF NURSING}

According to the Association for Nursing Professional development, the nursing professional development has been evolved over the years. Earlier focus for nursing standard was to establish relationship between continuing education and staff development. The latest focus of the nursing professional development includes facilitating professional role development by practice transitions, managing change, championing scientific enquiry, collaborating interprofessionally and advancing the roles as the leaders. The entire healthcare system is changing which brings new roles for the nurses. More care is being provided outside the acute care settings such as the clinics, home care and other specialized outpatient care settings. Nurse professional development practitioners play an important role to facilitate the professional role development of nurses and other healthcare professionals, encourage interprofessional education and collaboration. ${ }^{15}$

\section{IMPACT OF NURSING SERVICES IN PUBLIC HEALTH}

Nurses have been always playing an important role in improving nation's health and wellbeing. Nurses (public health nurse) also serve the people at their doorsteps by home visiting and help the community health care team by coordinating assessment, planning and providing health needs to the patients and family. They actively participate in community health promotion and disease prevention activities. According to American Public Health Association, Public health nurse provides the epidemiological data which are very important for understanding the peoples' experiences of health and illness. They identify the emerging potentially threats to the public health and appropriate actions are planned, coordinated and implemented. They also monitor the public health status indicators like environmentally caused illnesses, communicable disease occurrence, infant and maternal mortality rates etc which help significantly to identify the threats to public's health. ${ }^{16}$

\section{CONCLUSION}

Nurses, who play a major role in this Global pandemic make up more than half of all the healthcare workers worldwide. According to World Health Organization the world is still facing a short of six million nurses. It is like jumping in the battlefield without enough armed forces. Due to this shortage of nurse work force, it compelled the nurses to do overwork without proper time to rest. Nurses are working day and night without caring much of their own comfort and safety. Many have lost their lives and became infected while caring for the COVID-19 patients. In this crucial time nurses and midwives need constant support from the people to fight the pandemic. The contribution of the nursing professional towards health promotion and prevention is very important. The nurse's input in public health and hygiene can play a tremendous role in up gradation of the general health status of the community. It is essential to incorporate the nursing professionals in development of the public health.

\section{REFERENCE}

1. Worldometer. COVID-19 Corona virus Pandemic. [Internet]. 2020.[updated 2020 Oct. 05; cited 2020 Oct. 05] Available from www.worldometers.info.

2. Healthcare Radius. Role of nursing in COVID-19 management. [Internet]. 2020.[updated 2020 May. 11; cited 2020 Sep. 28] Available from www.healthcareradius.in

3. The Indian express. Three nurses in the Capital describe their role in COVID-19 fight. [Internet]. 2020.[updated 2020 May. 19; cited 2020 Sep. 28] Available from www.Indianexpress.com

4. Shu-Ching Chen, Yeur-Hur Lai, Shiow-Luan Tsay. Nursing perspectives on the impacts of COVID-19. $J$ of nursing research. 2020; 28(3): e85

5. Morin H. Karen, Baptiste Diana. Nurses as heroes, warriors and political activists. J of Clin. Nursing, 2020;29:2733-2733

6. The Conversation. Nurses on the frontlines: A history of heroism from Florence Nightingale to Coronavirus [Internet]. 2020.[updated 2020 May. 12; cited 2020 Sep. 24] Available from www.theconversation.com

7. Impact of the COVID-19 pandemic on Healthcare workers. [Internet]. 2020 [updated 2020 Oct. 02; cited 2020 Oct.05] Available from www. Wekipedia.org 
8. Healthcare Radius. Overcoming challenges faced by nurses. [Internet]. 2020.[updated 2020 May. 18; cited 2020 Sep. 27] Available from www.healthcareradius.in

9. Joseph Bobby, Joseph Merlyn. The health of healthcare workers. Indian J Occup Environ Med. 2020;20(2):71-72

10. Healthcare Radius. $90 \%$ Nurses in India face musculoskeletal pain: A study. [Internet]. 2020.[updated 2020 April. 6; cited 2020 Sep. 29] Available from www.healthcareradius.in

11. The Economics Times. Healthcare Workers are warriors, will set up helpline to redress of complaints: Center to SC. [Internet]. 2020. [updated 2020 April. 15; cited 2020 Sep. 29] Available from www. Economictimes.com

12. WHO. Caring for COVID-19 patients: Nurses across the Country share their journey. [Internet]. 2020.[updated 2020 May. 12; cited 2020 Sep. 30] Available from www. Who.int.

13. CIMS Today. A degree of respect: The nursing warriors who walk the wards, while we sleep on [Internet]. 2017. [updated 2017 Nov. 16; cited 2020 Sep. 26] Available from www. Today.mims.com

14. Coster Samantha et. al. What is the impact of professional nursing on patients' outcome globally? An overview of research evidence. Int. J Nurs Stud. 2018;78:76-83

15. Brunt A. Barbara, Morris M. Melanie.Nursing Professional Development (NPD). Statpearls [Internet] 2020. [updated 2020 Sep. 07; cited 2020 Sept. 25] Available from www.ncbi.nlm.nih.gov

16. Missouri department of Health and Senior Services. Role of public Health Nurses. Internet] Available from

https://health.mo.gov/living/lpha/phnursing/phnrole s.php 